\title{
Screening for cognitive impairment in late onset depression in a Brazilian sample using the BBRC-EDU
}

\author{
Tânia Maria da Silva Novaretti ${ }^{1}$, Marcia Radanovic², Ricardo Nitrini ${ }^{3}$
}

\begin{abstract}
Depression and dementia are the most prevalent neuropsychiatric disorders in the elderly population. Alzheimer's disease is the leading cause of dementia in most countries, being responsible for more than half of all dementia cases. Late-onset depression is a frequent cause of cognitive decline in the elderly. Differentiating between cognitive impairment secondary to depression and incipient dementia poses a challenge in the clinical setting. Objective: To evaluate the performance of elderly depressed patients using the BBRC-Edu. Methods: We studied 25 patients with late onset depression (mean age: 73.6 y (6.6); schooling: 9.1 y (5.7)) and 30 patients with mild $A D$ (mean age 76.6 y (5.4); schooling: 7.5 y (7.1)), who were compared to a control group of 30 healthy elderly (mean age 73.8 y (5.8); schooling: 9.1 y (5.4)) using the CERAD and BBRC-Edu batteries. Results: For the CERAD battery, depressed patients performed better than AD patients on all tasks $(p<0.0001)$ except for Constructional Praxis ( $p>0.05)$, and performed poorer than controls on verbal fluency (animals) and Word List Recall tasks $(\mathrm{p}<0.0001)$. For the BBRC-Edu, depressed patients performed better than AD patients on all tasks $(p<0.0001)$ except for Digit Span (direct order) $(p=0.076)$ and Incidental Memory $(p>0.05)$, and performed worse than controls on Learning (second presentation) and verbal fluency (fruits) tasks $(p<0.0001)$. Conclusion: Overall performance on the BBRC-Edu allowed differentiation of controls and depressed patients from AD patients.
\end{abstract}

Key words: Alzheimer's disease, CERAD, BBRC-Edu, depression, screening test, cognition, elderly.

\section{RASTREIO DE COMPROMETIMENTO COGNITIVO NA DEPRESSÃO DE INÍCIO TARDIO EM UMA AMOSTRA BRASILEIRA USANDO O BBRC-EDU}

RESUMO: Depressão e demência são os transtornos neuropsiquiátricos de maior prevalência na população idosa. A doença de Alzheimer é a principal causa de demência na maioria os países, sendo a responsável por mais da metade dos casos de demência. Depressão de início tardio é uma causa frequente de declínio cognitivo no idoso. A diferenciação entre transtorno cognitivo secundário à depressão e demência em fase inicial é um desafio na prática clínica. Objetivo: Avaliar o desempenho de pacientes idosos deprimidos usando a Bateria Breve de Rastreio Cognitivo (BBRC-Edu). Métodos: Estudamos 25 pacientes com depressão de início tardio, (idade média 73,6 (6,6); escolaridade: 9,1 (5,7)) e 30 pacientes com DA leve (CDR=1), (idade média 76,6 (5,4); escolaridade: 7,5 (7,1)). 0 desempenho de ambos os grupos foi comparado a um grupo controle de 30 idosos sadios (idade média 73,8 (5,8); escolaridade: 9,1 (5,4)). Resultados: Na Bateria CERAD pacientes deprimidos tiveram desempenho melhor que pacientes com DA em todos os testes $(p<0,0001)$ exceto para Praxia Construcional ( $p>0,05)$, e desempenho pior que os controles na fluência verbal (animais) e Recordação da Lista de Palavras $(p<0,0001)$. Na BBRC-Edu, pacientes deprimidos tiveram melhor desempenho comparados aos pacientes com DA em todos os testes $(p<0,0001)$ exceto para Spam de Dígitos (ordem direta) $(p=0,076)$ e Memória Incidental ( $p>0,05)$, e tiveram desempenho pior que os controles na Aprendizagem (segunda apresentação) e na fluência verbal (frutas) ( $p<0,0001)$. Conclusão: A Bateria Breve de Rastreio Cognitivo permite a diferenciação de controles e pacientes com transtorno depressivo, de pacientes com doença de Alzheimer.

Palavras-chave: doença de Alzheimer, CERAD, BBRC-Edu, depressão, testes de rastreio, cognição, idosos.

${ }^{1}$ State University Paulista Julio de Mesquita Filho, Faculty of Sciences, Marília Campus, Department of Speech, Marilia SP, Brazil. ${ }^{2}$ Behavioral and Cognitive Neurology Unit, Department of Neurology, University Department of Neurology, University of São Paulo School of Medicine, São Paulo SP, Brazil. ${ }^{3}$ Behavioral and Cognitive Neurology Unit, Department of Neurology, and Cognitive Disorders Reference Center (CEREDIC), Hospital das Clínicas of the University of São Paulo School of Medicine, São Paulo SP, Brazil.

Tânia Maria da Silva Novaretti. Rua Carlos Botelho, 520 - 17516-190 Marília SP - Brazil. E-mail: tanianovaretti@terra.com.br

Disclosure: The authors report no conflicts of interest. Received February 2, 2012 Accepted in final form May 3, 2012 


\section{INTRODUCTION}

epression and dementia are two of the most prevalent neuropsychiatric diseases in the elderly, yet this population is far from homogeneous in terms of cognitive decline and depressive symptoms. Major depressive disorder is common in the general population having an estimated lifetime prevalence of $15-17 \%{ }^{1}$ Clinically significant depressive symptoms are present in $11-39 \%$ of older adults ${ }^{2-4}$ while cognitive impairment is estimated to affect $17-36 \%$ of adults aged over 65 years. ${ }^{4-6}$ Elderly demented patients have shown an even higher prevalence of depression (24\%) in epidemiological studies. ${ }^{7}$

Age-related cognitive decline is usually characterized by mild impairment in a number of cognitive domains, ${ }^{8}$ typically manifested as changes in episodic memory or reduced ability to access information stored in longterm memory ${ }^{9,10}$ resulting from decreased speed of the central processing required to encode and retrieve information. ${ }^{11}$ In this population, working memory becomes affected ${ }^{12,13}$ while retention usually remains preserved ${ }^{8,12}$ as does implicit memory. ${ }^{14}$ Other changes associated with normal aging include mild deficits in language functioning (naming, verbal fluency), visuospatial abilities, perceptual speed and executive functioning. ${ }^{15-17}$ Amongst patients who suffer from late-life depression, $20-50 \%$ display deficits across a wide range of cognitive domains including processing speed, ${ }^{18}$ attention and executive functions $s^{19,20}$ as well as episodic and working memory. ${ }^{21}$

Furthermore, the level of generalized cognitive impairment associated with depression can be so marked in the elderly that depression is often misdiagnosed as dementia. Indeed, $9-43 \%$ of elderly persons who have depression subsequently develop some kind of dementia. ${ }^{22}$ This cognitive impairment can persist despite improvement in depressive symptoms. ${ }^{2,23}$ However, the true pattern of cognitive impairment in late-onset depression remains a matter of controversy because most studies available are modest or small in size, and cognitive deficits tend to differ in both nature and severity, between and within studies. ${ }^{24}$

In view of the above-mentioned interrelationship between depression and $\mathrm{AD}$, diagnosing dementia in depressed patients, regardless of depression, poses a challenge. ${ }^{25}$ The aim of this study was to evaluate the performance of elderly depressed patients, healthy elderly, and patients with early stage $\mathrm{AD}$ using the BBRC-Edu, a screening battery fully developed by Brazilian researchers. ${ }^{26}$ To the best of our knowledge, this is the first study to employ the BBRC-Edu in the assessment of depressed elderly.

\section{METHODS}

Thirty patients with mild AD, 25 with depression and 30 control subjects were studied. All participants were native speakers of Brazilian Portuguese, aged over 60 years, and had at least 2 years of formal education. Subjects with a past history or neurological evidence of stroke, neurodegenerative disorders, head injury, serious noncompensated medical illness, drug abuse, hearing, visual or motor impairment that could have affected their cognitive performance were not included. The control group was defined as subjects living in the community, who fulfilled the MOANS criteria ${ }^{27}$ and achieved normal scores on the cognitive evaluation (corrected for age and schooling). The diagnosis of depression was determined according to the DSM-IV criteria, ${ }^{28}$ while the diagnosis of Probable AD was based on the NINCDS-ADRA criteria. ${ }^{29}$ Only mild AD patients (CDR 1 ) were included. ${ }^{30}$

The cognitive evaluation entailed application of the Brazilian version of the Consortium to Establish a Registry for Alzheimer's Disease Battery (CERAD). ${ }^{31,32}$ Depressive symptoms were evaluated using the Geriatric Depression Scale (GDS), ${ }^{33}$ the Hamilton Depression Scale (HAM-D), ${ }^{34}$ and the Montgomery \& Asberg Depression Rating Scale (MADRS). ${ }^{35,36}$ Functional abilities were assessed using the Pfeffer Functional Activities Questionnaire (PFAQ). ${ }^{37}$ Depressed patients were evaluated within one week of introducing antidepressant medication.

After the initial evaluation, subjects were classified into controls, depression or mild AD. Participants were then assessed using the Brief Cognitive Battery-Edu (BBRC-Edu), which was developed in Brazil and has proven suitable for screening cognitive impairment in the Brazilian population, being less impacted by educational level. ${ }^{26}$

The performance of the three groups on each task was compared using one-way ANOVA with Tukey's post-hoc test. All statistical analyses were performed using the SPSS for Windows ${ }^{\circledR}$ 10.0.1 software, and a significance level of 0.05 was adopted.

This study was approved by the local Research Ethics Committee (Hospital das Clínicas - University of São Paulo School of Medicine) and all participants or their legal representatives signed an informed consent prior to enrolling on the study.

\section{RESULTS}

The demographic and clinical characteristics of the 
sample are shown in Table 1 . The mean values for age and schooling level were similar across the three groups. Women predominated in the depression and $\mathrm{AD}$ groups. $\mathrm{AD}$ patients had lower scores on the $\mathrm{PFAQ}$, as expected. Controls and Depression patients did not differ for PFAQ scores. All groups differed in GDS, HAM-D and MADRS scores, with patients from the Depression group exhibiting the highest scores while patients from the $\mathrm{AD}$ group had scores between those of the Control and Depression groups.

Table 2 shows performance of the three groups on the CERAD battery. Depressed patients performed better than $\mathrm{AD}$ patients on all tasks except for Constructional Praxis, but performed poorer than controls on verbal fluency (animals) and Word List Recall tasks.

On the BBRC-Edu, depressed patients performed

Table 1. Demographic and clinical characteristics of the sample.

\begin{tabular}{|c|c|c|c|c|c|}
\hline Variable & & $\begin{array}{c}\text { CG } \\
\text { Mean (SD) range }\end{array}$ & $\begin{array}{c}\text { DG } \\
\text { Mean (SD) range } \\
\end{array}$ & $\begin{array}{c}\text { AD } \\
\text { Mean (SD) range }\end{array}$ & $\begin{array}{c}\text { p (two-tailed) } \\
\text { Multiple comparison }\end{array}$ \\
\hline Age & & $73.8(5.8) 60-87$ & 73.6 (6.6) 65-93 & 77.6 (5.4) 60-85 & $0.055^{\star}$ \\
\hline Schooling & & $9.1(5.4) 2-23$ & $9.1(5.7) 2-20$ & $7.5(7.1)$ 2-33 & $0.519^{*}$ \\
\hline \multirow[t]{3}{*}{ Gender } & M & 16 & 20 & 23 & $0.0005^{\star \star}$ \\
\hline & $\mathrm{F}$ & 14 & 5 & 7 & $C G \times D G p=0.005$ \\
\hline & & & & & $C G \times A D p=0.006$ \\
\hline PFAQ & & $\begin{array}{l}0(0) \\
0-0\end{array}$ & $\begin{array}{c}1.2(2) \\
0-5\end{array}$ & $\begin{array}{c}19.9(5.2) \\
5-28\end{array}$ & $\begin{array}{c}<0.0001^{*} \\
C G \& D G \times A D(p<0.0001)\end{array}$ \\
\hline GDS & & $\begin{array}{c}2.2(2.6) \\
0-9 \\
\end{array}$ & $\begin{array}{c}24.6(4.6) \\
16-30\end{array}$ & $\begin{array}{c}10.3(4.5) \\
3-17\end{array}$ & $\begin{array}{l}<0.0001^{*} \\
\text { all groups differ }\end{array}$ \\
\hline HAM-D & & $\begin{array}{c}2.4(3.9) \\
0-20 \\
\end{array}$ & $\begin{array}{c}32.8(5.4) \\
27-46\end{array}$ & $\begin{array}{c}14.6(8.3) \\
1-26 \\
\end{array}$ & $\begin{array}{l}<0.0001^{*} \\
\text { all groups differ }\end{array}$ \\
\hline MADRS & & $\begin{array}{c}2.4(5) \\
0-24\end{array}$ & $\begin{array}{c}36.3(7.2) \\
30-51\end{array}$ & $\begin{array}{c}16.5(8.4) \\
2-28\end{array}$ & $\begin{array}{l}<0.0001^{*} \\
\text { all groups differ }\end{array}$ \\
\hline
\end{tabular}

CG: control group; DG: depression group; F: female; M: male; NA: not applicable; *ANOVA with Tukey's post hoc test; ${ }^{* *}$ Chi-square test.

Table 2. Performance of the three groups on the CERAD battery.

\begin{tabular}{|c|c|c|c|c|}
\hline Variable & $\begin{array}{c}\text { CG } \\
\text { Mean (SD) range }\end{array}$ & $\begin{array}{c}\text { DG } \\
\text { Mean (SD) range }\end{array}$ & $\begin{array}{c}\text { AD } \\
\text { Mean (SD) range }\end{array}$ & $\begin{array}{c}\text { p (two-tailed)* } \\
\text { Multiple comparison }\end{array}$ \\
\hline Verbal fluency (Animals) & $\begin{array}{c}18.1(4) \\
14-30\end{array}$ & $\begin{array}{c}15.1(2.3) \\
12-20\end{array}$ & $\begin{array}{c}9.7(2.8) \\
0-14\end{array}$ & $\begin{array}{l}<0.0001 \\
\text { all differ }\end{array}$ \\
\hline Naming 15 items & $\begin{array}{c}13.2(1.7) \\
10-15\end{array}$ & $\begin{array}{c}12.9(1.7) \\
10-15\end{array}$ & $\begin{array}{c}10.6(2.1) \\
5-14\end{array}$ & $\begin{array}{c}<0.0001 \\
C G \& D G \times A D(p<0.0001)\end{array}$ \\
\hline MMSE & $\begin{array}{c}27.2(1.4) \\
23-30\end{array}$ & $\begin{array}{c}26(2.3) \\
21-30\end{array}$ & $\begin{array}{c}20.7(3.2) \\
13-26\end{array}$ & $\begin{array}{c}<0.0001 \\
C G \& D G \times A D(p<0.0001)\end{array}$ \\
\hline Word List Memory & $\begin{array}{c}15.8(3) \\
12-24\end{array}$ & $\begin{array}{c}15.3(3.1) \\
18-24\end{array}$ & $\begin{array}{c}7.9(3.8) \\
2-16\end{array}$ & $\begin{array}{c}<0.0001 \\
C G \& D G \times A D(p<0.0001)\end{array}$ \\
\hline Constructional Praxis & $\begin{array}{c}9.7(1.7) \\
7-11\end{array}$ & $\begin{array}{c}9.2(1.9) \\
7-13\end{array}$ & $\begin{array}{c}8.1(2.9) \\
4-13\end{array}$ & $\begin{array}{c}0.022 \\
C G \times A D(p<0.018)\end{array}$ \\
\hline Word List Recall & $\begin{array}{c}4.7(1.6) \\
3-10\end{array}$ & $\begin{array}{c}3.4(1.2) \\
1-7\end{array}$ & $\begin{array}{c}0.7(0.9) \\
0-3\end{array}$ & $\begin{array}{l}<0.0001 \\
\text { all differ }\end{array}$ \\
\hline Word List Recognition & $\begin{array}{c}8.9(0.8) \\
7-10\end{array}$ & $\begin{array}{c}8.3(1.5) \\
5-10\end{array}$ & $\begin{array}{c}4.3(2.8) \\
0-10\end{array}$ & $\begin{array}{c}<0.0001 \\
C G \& D G \times A D(p<0.0001)\end{array}$ \\
\hline Praxis Recall & $\begin{array}{c}7.6(3.1) \\
2-11\end{array}$ & $\begin{array}{c}6.3(2.9) \\
2-11\end{array}$ & $\begin{array}{c}1.5(2.4) \\
0-10\end{array}$ & $\begin{array}{c}<0.0001 \\
C G \& D G \times A D(p<0.0001)\end{array}$ \\
\hline
\end{tabular}

CG: control group; DG: depression group; F: female; M: male; NA: not applicable; *ANOVA with Tukey's post hoc test. 
Table 3. Performance of the three groups on the BBRC-Edu battery.

\begin{tabular}{|c|c|c|c|c|c|}
\hline Variable & & $\begin{array}{c}\text { CG } \\
\text { Mean (SD) range }\end{array}$ & $\begin{array}{c}\text { DG } \\
\text { Mean (SD) range }\end{array}$ & $\begin{array}{c}\text { AD } \\
\text { Mean (SD) range }\end{array}$ & $\begin{array}{c}\text { p (two-tailed)* } \\
\text { Multiple comparison }\end{array}$ \\
\hline \multirow[t]{2}{*}{ Digit Span } & Direct order & $\begin{array}{c}8.8(1.7) \\
6-12 \\
\end{array}$ & $\begin{array}{c}8.9(1.4) \\
6-12 \\
\end{array}$ & $\begin{array}{c}7.9(1.9) \\
5-11\end{array}$ & 0.076 \\
\hline & Reverse order & $\begin{array}{c}4.5(1.5) \\
2-8\end{array}$ & $\begin{array}{c}4.1(1.5) \\
2-8\end{array}$ & $\begin{array}{c}2.8(1.6) \\
1-8\end{array}$ & $\begin{array}{c}0.0001 \\
C G \times A D(p<0.0001) \\
D G \times A D(p=0.004)\end{array}$ \\
\hline \multirow[t]{8}{*}{ Learning and memory } & Perception/Naming & $\begin{array}{r}10(0) \\
10-10 \\
\end{array}$ & $\begin{array}{r}10(0) \\
10-10 \\
\end{array}$ & $\begin{array}{c}9.8(0.3) \\
9-10 \\
\end{array}$ & $\begin{array}{c}0.020 \\
C G \& D G \times A D(p=0.037)\end{array}$ \\
\hline & Incidental memory & $\begin{array}{c}4.7(1.4) \\
3-9\end{array}$ & $\begin{array}{c}4.1(1.5) \\
2-7\end{array}$ & $\begin{array}{c}3.5(1.7) \\
0-7\end{array}$ & $\begin{array}{c}0.011 \\
C G \times A D(p=0.008)\end{array}$ \\
\hline & Learning 1 & $\begin{array}{c}7(1.4) \\
5-10\end{array}$ & $\begin{array}{c}6.7(2) \\
3-10 \\
\end{array}$ & $\begin{array}{c}4.6(1.7) \\
1-8 \\
\end{array}$ & $\begin{array}{c}<0.0001 \\
C G \& D G \times A D(p<0.0001)\end{array}$ \\
\hline & Learning 2 & $\begin{array}{c}8.9(0.9) \\
7-10\end{array}$ & $\begin{array}{c}7.4(1.9) \\
3-10\end{array}$ & $\begin{array}{c}5.2(1.3) \\
2-8\end{array}$ & $\begin{array}{l}<0.0001 \\
\text { all differ }\end{array}$ \\
\hline & Delayed recall & $\begin{array}{c}7.5(1.7) \\
4-10\end{array}$ & $\begin{array}{c}6.3(2.3) \\
2-10\end{array}$ & $\begin{array}{c}2.4(2.2) \\
0-7\end{array}$ & $\begin{array}{c}<0.0001 \\
C G \times A D(p<0.001) \\
D G \times A D(p<0.0001)\end{array}$ \\
\hline & Picture recognition & $\begin{array}{c}9.7(0.5) \\
8-10\end{array}$ & $\begin{array}{c}9.5(0.8) \\
7-10\end{array}$ & $\begin{array}{c}6.9(2.8) \\
0-10\end{array}$ & $\begin{array}{c}<0.0001 \\
C G \& D G \times A D(p<0.0001)\end{array}$ \\
\hline & Verbal fluency (Fruits) & $\begin{array}{c}15.6(2.4) \\
13-23\end{array}$ & $\begin{array}{l}13(2) \\
7-16\end{array}$ & $\begin{array}{c}9(2.7) \\
4-16\end{array}$ & $\begin{array}{l}<0.0001 \\
\text { all differ }\end{array}$ \\
\hline & Clock drawing & $\begin{array}{c}9.3(1.6) \\
2-10\end{array}$ & $\begin{array}{c}8.4(2) \\
3-10\end{array}$ & $\begin{array}{c}4.9(2.5) \\
2-10\end{array}$ & $\begin{array}{c}<0.0001 \\
C G \& D G \times A D(p<0.0001)\end{array}$ \\
\hline
\end{tabular}

CG: control group; DG: depression group; F: female; M: male; NA: not applicable; *ANOVA with Tukey's post hoc test.

better compared with $\mathrm{AD}$ patients on all tasks except for Digit Span (direct order) and Incidental Memory, yet performed worse than controls on Learning (second presentation), and verbal fluency (fruits) tasks. For the two latter tasks, depressed patients showed an intermediate performance compared to controls and $\mathrm{AD}$ patients (Table 3).

\section{DISCUSSION}

The choice of psychometric tests for use in Portuguesespeaking people classified into well-defined groups is limited. ${ }^{32}$ It is difficult to discriminate early dementia from depression based on clinical and neuropsychological evidence ${ }^{37}$ because similar cognitive and affective problems can occur in both mild $\mathrm{AD}$ and "depressive pseudo-dementia". ${ }^{39}$ The hallmark of $\mathrm{AD}$ is marked impairment in episodic memory, which may exist years before a clinical diagnosis of dementia is established. ${ }^{40,41}$ However, semantic impairments also occur in approximately $50 \%$ of patients with mild $A D$ where semantic memory may be the most important cognitive domain for performing everyday skills. ${ }^{10,42}$

Depression is particularly associated with deficits in executive control processes. ${ }^{43,44}$ Patients with late-onset depression have demonstrated impairments in executive functioning, processing speed, as well as episodic and semantic memory. ${ }^{45}$ Notwithstanding, few studies in the literature on late-onset depression have investigated semantic memory. However, semantic memory tasks often require preserved executive function. Category fluency for example, although generally regarded as a valid measure of semantic memory, relies heavily on initiation, which may be impaired in depression. ${ }^{45}$ In addition, the individual under test is required to perform this task within a set time limit, which makes processing speed an important factor for good performance. ${ }^{46}$ In the present study, depressed patients consistently displayed impairment in verbal fluency, both for animal and fruits categories.

The presence of depression-related deficits in geriatric depression has been noted in episodic memory. ${ }^{23,47-49}$ Sheline et al. $2006^{49}$ and Delaloyle et al. $2008^{50}$ have suggested that while slowed processing speed appears to be the core cognitive deficit in late-onset depression, it was closely followed by executive dysfunction. However, these authors hold that episodic memory impair- 
ment cannot be explained solely by processing resource decreases in late-onset depression patients. Recent data suggest that the reduction in processing resources is a primary cognitive decrement in late-onset depression, which subsequently induces higher-level cognitive deficits. ${ }^{18-21,49}$ For instance, besides memory, impaired language abilities in old age have been associated with a reduction in processing resources, such as processing speed, working memory span and inhibition capacity. Processing speed, which denotes the pace at which elementary cognitive operations are carried out, is reduced in late-onset depression..$^{21}$ Depression-related variance on higher-order cognitive tests is also thought to be mediated by reduced working memory span, which is able to maintain or suppress the activation of long-term memory units and allocation of intentional resources. Finally, inefficient inhibitory processes permit the entry and maintenance of irrelevant information in the working memory, affecting subsequent cognitive performance..$^{50}$ In this study, depressed patients did not differ from controls in cued recall memory tasks (recognition) for verbal and non-verbal stimuli, thus suggesting an impairment of self-generated retrieval strategies, which may be secondary to lower processing speed associated to executive dysfunction.

In the clinical setting, it may be difficult to differentiate depression from incipient $A D$ in patients with cognitive impairment. Brief cognitive tests may be helpful in assessing patients with suspected dementia in primary care facilities provided these instruments are sufficiently accurate. By comparing the performance of controls, depressed patients and mild AD patients using a wellaccepted battery (CERAD) plus a battery developed in Brazil (BBRC-Edu), we found that the latter was suitable for detecting mild cognitive impairment in depressed patients and also proved able to discriminate this group from $\mathrm{AD}$ patients. Further studies are warranted in order to establish the degree of agreement between the BBRC-Edu and other broadly used screening tests, such as the MMSE and CERAD.

\section{REFERENCES}

1. APA. Diagnostic and Statistical Manual of Mental Disorders. American Psychiatric Association: Washington, DC; 1994.

2. Steffens DC, Skoog I, Norton MC, et al. Prevalence of depression and its treatment in an elderly population: The Cache County study. Arch Gen Psychiatry 2000;57:601-607.

3. Copeland JR, Beekman AT, Braam AW, et al. Depression among older people in Europe: The EURODEP Studies. World Psychiatry 2004;3: 45-49.

4. Lee Y, Shinkai S. Correlates of cognitive impairment and depressive symptoms among older adults in Korea and Japan. Int J Geriatr Psychiatry 2005;20:576-586.

5. Rait G, Fletcher A, Smeeth L, et al. Prevalence of cognitive impairment: results from the MCR trial of assessment and management of older people in the community. Age Aging 2005;34:242-248.

6. Graciani A, Banegas JR, Guallar-Castillon P, Domínguez-Rojas V, Rodríguez-Artalejo F. Cognitive assessment of the non-demented elderly community dwellers in Spain. Dement Geriatr Cogn Disord 2006;21: 104-112.

7. Lyketsos CG, Steinberg M, Tschanz JT, Norton MC, Steffens DC, Breitner JC. Mental and behavioral disturbances in dementia: findings from the Cache Country Study on Memory in Aging. Am J Psychiatry 2000;157,708-714.

8. Petersen RC, Stevens JC, Ganguli M, Tangalos EG, Cummings JL, DeKosky ST. Practice parameter: Early detection of dementia: Mild cognitive impairment (an evidence-based review). Neurology 2001;56: 1133-1142.

9. Dixon RA, Wahlin A, Maitland SB, Hultsch DF, Hertzog C, Backman L. Episodic memory change in late adulthood: generalizability across samples and performances indices. Memory Cognit 2004;32:768-778.

10. Amieva H, Goff ML, Millet X, et al. Prodromal Alzheimer's disease: successive emergence of the clinical symptoms. Ann Neurol 2008;64: 492-498.

11. Carlson MC, Xue QL, Zhou J, Fried LP. Executive decline and dysfunction precedes declines in memory: the women's health and aging study II. J Gerontol 2009;64A:110-117.

12. Rabinowitz JC, Craik FI. Prior retrieval effects in young and old adults. J Gerontol 1986;41:368-375.

13. Hultsch DF, Hertzog C, Small BJ, McDonald-Miszczak L, Dixon RA. Short-term longitudinal change in cognitive performance in later life. Psychol Aging 1992;7:571-584.

14. Ritchie K, Touchon J, Ledesert B, Leibovici D, Gorce AM. Establishing the limits and characteristics of normal age-related cognitive decline. Rev Epidemiol Sante Publique 1997;45:373-381.

15. Rubin EH, Storandt M, Miller JP, et al. A prospective study of cognitive function and onset of dementia in cognitively healthy elders. Arch Neurol 1998;55:395-401.

16. Salthouse T. Mechanisms of age-cognition relations in adulthood. Hillsdale, NJ: Lawrence Erlbaum Associates; 1989.

17. Schaie KW. Perceptual speed in adulthood: Cross-sectional and longitudinal studies. Psychol Aging 1989;4:443-453.

18. Butters MA, Whyte EM, Nebes RD, et al. The nature and determinants of neuropsychological functioning in late-life depression. Arch Gen Psychiatry 2004;61:587-595.

19. Lockwood KA, Alexopoulos GS, Van Gorp WG. Executive dysfunction in geriatric depression. Am J Psychiatry 2002;159:1119-1126.

20. Rapp MA, Dahlman K, Sano M, Grossman HT, Haroutunian V, Gorman JM. Neuropsychological differences between late-onset and recurrent geriatric major depression. Am J Psychiatry 2005;162:691-698.

21. Nebes RD, Butters MA, Mulsant BH, et al. Decreased working memory and processing speed mediate cognitive impairment in geriatric depression. Psychol Med 2000; 30:679-691.

22. Stek ML, Van Exel E, Van Tilburg W, Westendorp RGJ, Beekman ATF. The prognosis of depression in old age: outcome six to eight years after clinical treatment. Aging Ment Health 2002;6:282-285.

23. Bhalla RK, Butters MA, Mulsant BH. Persistence of neuropsychological deficits in the remitted state of late-life depression. Am J Geriatr Psychiatry 2006;14:419-427.

24. Rose EJ, Ebmeier KP. Pattern of impaired working memory during major depression. J Affect Disord 2006;90:149-161.

25. Novaretti TMS, D'Avila Freitas MI, Mansur LL, Nitrini R, Radanovic M. Comparison of language impairment in late-onset depression and Alzheimer's disease. Acta Neuropsychiatr 2011;23:62-68.

26. Nitrini R, Caramelli P, Porto CS, Fichman HC, Formigoni AP. Brief cognitive battery in the diagnosis of mild Alzheimer's disease in subjects with medium and high levels of education. Dement Neuropsychol 2007;1: 32-36.

27. Smith GE, Ivnik RJ. Normative neuropsychology. In: Petersen RC: Mild Cognitive Impairment, New York: Oxford; 2003:63-88.

28. Spitzer RL, Williams JB, Gibbon M, First MB. The Structured Clinical Interview for DSM-III-R (SCID). I: History, rationale and description. Arch Gen Psychiatry 1992;49:624-629. 
29. McKhann G, Drachman D, Folstein M, Katzman R, Price D, Stadian EM. Clinical diagnosis of Alzheimer's disease: Report of the NINCDSADRDA Work Group under the auspices of Department of Health and Human Services Task Force on Alzheimer's disease. Neurology 1984; 34:939-944.

30. Hodges JR, Salmon DP, Butters N. Semantic memory impairment in Alzheimer's disease: failure of access or degraded knowledge. Neuropsychologia 1992;30:301-14.

31. Morris JC, Heyman A, Mohs RC, et al. The Consortium to Establish a Registry for Alzheimer's Disease (CERAD). Part I: Clinical and neuropsychological assessment for Alzheimer's disease. Neurology 1989;39: 1159-1165.

32. Bertoluci PHF, Okamoto $I H$, Brucki SMD, Siviero MO, Toniolo Neto J, Ramos LR. Applicability of the CERAD neuropsychological battery to Brazilian elderly. Arq Neuropsychiatr 2001;59:532-536

33. Yesavage JA, Brink TL, Rose TL, et al. Development and validation of geriatric depression screening scale: a preliminary report. J Psychiatr Res 1983;17:37-49.

34. Hamilton M. A rating scale for depression. J Neurol Neurosurg Psychiatry 1960;23:56-62.

35. Montgomery AS, Asberg M. New depression scale designed to be sensitive to change. Br J Psychiatry 1979;134:382.

36. Moreno RA, Moreno DH. Escalas de depressão de Montgomery \& Åsberg (MADRS) e de Hamilton (HAM-D). Rev Psiq Clin 1998;25:262-272.

37. Pfeffer RI, Kurosaki T, Harrah CH Jr, Chance JM, Filos S. Measurement of functional activities in older adults in the community. J Gerontol 1982;37:323-329.

38. Foldi NS, Brickman AM, Schaefer LA, Knutelska ME. Distinct serial position profiles and neuropsychological measures differentiate late life depression from normal aging and Alzheimer's disease. Psychiatry Res 2003:120:71-84.

39. Swainson R, Hodges JR, Galton CJ, et al. Early detection and differen- tial diagnosis of Alzheimer's disease and depression with neuropsychological tasks. Dement Geriatr Cogn Disord 2001;12:265-280.

40. Backman L, Small B, Fratiglioni L. Stability of the preclinical episodic memory deficit in Alzheimer's disease. Brain 2001;124: 96-102.

41. Chen P, Ratcliff G, Belle SH. Patterns of cognitive decline in presymptomatic Alzheimer disease: a prospective community study. Arch Gen Psychiatry 2001;58:853-858.

42. Perry RJ, Hodges JR. Relationship between functional and neuropsychological performance in early Alzheimer's disease. Alzheimer Dis Assoc Disord 2000;14:1-10.

43. Henry JD, Crawford JR. Verbal fluency performance in dementia of the Alzheimer type; a meta-analysis. Neuropsychologia 2005;42:12121222.

44. Henry JD, Crawford JR. A meta-analytic review of verbal fluency deficits in depression. J Clin Exp Neuropsychol 2005;27:78-101.

45. Herrmann LL, Goodwin GM, Ebmeier KP. The cognitive neuropsychology of depression in the elderly. Psychol Med 2007;37:1693-1702.

46. Norris MP, Blankenship-Reuter I, Snow-Turek Al, Finch J. Influence of depression on verbal fluency performance. Age Cog 1995;2:206 -215.

47. Portela MJ, Marcos T, Rami L, Navarro V, Gasto C, Salamero M. Residual cognitive impairment in late-life depression after a 12-month period follow-up. Int J Geriatr Psychiatry 2003;18:571-576.

48. King DA, Cox C, Lyness JM, Conwell Y, Caine ED. Quantitative and qualitative differences in the verbal learning performance of elderly depressives and healthy controls. J Int Neuropsychol Soc 2006;4: 115-126.

49. Sheline YI, Barch DM, Garcia K, et al. Cognitive function in late life depression: relationships to depression severity, cerebrovascular risk factors and processing speed. Biol Psychiatry 2006;60:58-65.

50. Delaloye C, Baudois S, Bilbao F, et al.Cognitive impairment in late-onset depression. Limited to a decrement in information processing resources? Eur Neurol 2008;60:149-154. 